\title{
Environmental impact of thin-film GaInP/GaAs and multicrystalline silicon solar modules produced with solar electricity
}

\author{
Nellemieke Mohr • Arjen Meijer • \\ Mark A. J. Huijbregts • Lucas Reijnders
}

Received: 9 June 2008 / Accepted: 8 February 2009 /Published online: 24 March 2009

(C) The Author(s) 2009. This article is published with open access at Springerlink.com

\begin{abstract}
Background, aim, and scope The environmental burden of photovoltaic (PV) solar modules is currently largely determined by the cumulative input of fossil energy used for module production. However, with an increased focus on limiting the emission of $\mathrm{CO}_{2}$ coming from fossil fuels, it is expected that renewable resources, including photovoltaics, may well become more important in producing electricity. A comparison of the environmental impacts of PV modules in case their life cycle is based on the use of PV electricity in contrast to conventional electricity can elucidate potential environmental drawbacks in an early stage of development of a solar-based economy. The goal of this paper is to show for ten impact categories the environmental consequences of
\end{abstract}

Responsible editor: Niels Jungbluth

Electronic supplementary material The online version of this article (doi:10.1007/s11367-009-0062-z) contains supplementary material, which is available to authorized users.

N. Mohr $(\square) \cdot$ M. A. J. Huijbregts

Department of Environmental Science,

Radboud University Nijmegen,

Heyendaalseweg 135, 6525 AJ Nijmegen,

The Netherlands

e-mail: N.Mohr@science.ru.nl

A. Meijer

OTB Research Institute for Housing, Urban and Mobility Studies,

Delft University of Technology,

Jaffalaan 9, 2628 BX Delft,

The Netherlands

L. Reijnders

Institute for Biodiversity and Ecosystem Dynamics,

University of Amsterdam,

Nieuwe Achtergracht 166, 1018 WV Amsterdam,

The Netherlands replacing fossil electricity with solar electricity into the life cycle of two types of PV modules.

Materials and methods Using life cycle assessment (LCA), we evaluated the environmental impacts of two types of PV modules: a thin-film GaInP/GaAs tandem module and a multicrystalline silicon (multi-Si) module. For each of the modules, the total amount of fossil electricity required in the life cycle of the module was substituted with electricity that is generated by a corresponding PV module. The environmental impacts of the modules on the midpoint level were compared with those of the same modules in case their life cycle is based on the use of conventional electricity. The environmental impacts were assessed for Western European circumstances with an annual solar irradiation of $1000 \mathrm{kWh} / \mathrm{m}^{2}$. For the $\mathrm{GaInP} / \mathrm{GaAs}$ module, the environmental impacts of individual production steps were also analysed.

Results Environmental burdens decreased when PV electricity was applied in the life cycle of the two PV modules. The impact score reductions of the $\mathrm{GaInP} / \mathrm{GaAs}$ module were up to a factor of 4.9 (global warming). The impact score reductions found for the multi-Si module were up to a factor of 2.5 (abiotic depletion and global warming). Reductions of the toxicity scores of both module types were smaller or negligible. This is caused by a decreased use of fossil fuels, on the one hand, and an increased consumption of materials for the production of the additional solar modules used for generating the required PV electricity on the other. Overall, the impact scores of the GaInP/GaAs module were reduced more than the corresponding scores of the multi-Si module. The contribution analysis of the GaInP/ GaAs module production steps indicated that for global warming, the cell growth process is dominant for supply with conventional electricity, while for the solar scenario, the frame becomes dominant. Regarding freshwater aquatic 
ecotoxicity scores associated with the life cycle of the GaInP/ GaAs module, the cell growth process is dominant for supply with conventional electricity, while the reactor system for the cell growth with the associated gas scrubbing system is dominant for the solar scenario.

Discussion There are uncertainties regarding the calculated environmental impact scores. This paper describes uncertainties associated with the used economic allocation method, and uncertainties because of missing life cycle inventory data. For the $\mathrm{GaInP} / \mathrm{GaAs}$ module, it was found that the global warming impact scores range from $-66 \%$ to $+41 \%$, and the freshwater aquatic ecotoxicity scores (for an infinite time horizon) range from $-40 \%$ to $+300 \%$ compared to the default estimates. For both impact categories, the choices associated with the allocation of gallium, with the electricity mix, with the conversion efficiency of the commercially produced GaInP/GaAs cells, and with the yield of the cell growth process are most influential. For freshwater aquatic ecotoxicity, the uncertainty concerning the lifetime of the reactor system for the GaInP/GaAs cell growth process and the gas scrubbing system is particularly relevant.

Conclusions Use of PV electricity instead of fossil electricity significantly reduces the environmental burdens of the GaInP/GaAs and the multi-Si module. The reductions of the toxicity scores, however, are smaller or negligible. Toxicity impacts of the GaInP/GaAs cells can be reduced by improvement of the yield of the cell growth process, a reduced energy demand in the cell growth process, reduction of the amount of stainless steel in the cell growth reactor system and the gas scrubbing system, and a longer lifetime of these systems.

Recommendations and perspectives Because the greenhouse gas emissions associated with the production of fossil-fuel-based electricity have an important share in global warming on a world-wide scale, switching to a more extensive use of solar power is helpful to comply with the present international legislation on the area of global warming reduction. As reductions in toxicity impact scores are smaller or negligible when fossil electricity is replaced by PV electricity, it is desirable to give specific attention to the processes which dominantly contribute to these impact categories. Furthermore, in this study, a shift in ranking of several environmental impacts of the modules has been found when PV electricity is used instead of fossil electricity. The results of a comparative LCA can thus be dependent of the electricity mix used in the life cycles of the assessed products.

Keywords Electricity production - Environmental impact . Fossil fuels · GaInP/GaAs · Global warming · Life cycle assessment (LCA) · Multicrystalline silicon · Photovoltaics · Renewable energy . Thin-film solar cell · Toxicity

\section{Background, aim, and scope}

On a world-wide scale, the greenhouse gas emissions at the production of fossil-fuel-based electricity have an important share in the anthropogenic greenhouse gas emissions (IPCC 2007; Quadrelli and Peterson 2007; OECD 2008). Because the environmental burdens of electricity that is produced by photovoltaic (PV) solar modules are substantially lower than the burdens of electricity that is produced from fossil fuels (European Commission 1995-1998; Dones et al. 2004), it is expected that switching to a more extensive use of solar power is helpful in achieving a reduction of this share. In the past years, life cycle impacts of a variety of PV systems have been evaluated. Most of the studies refer to PV systems based on silicon (Si) solar cells (Gürzenich et al. 1999; Keoleian and Lewis 2003; Dones et al. 2004; Gürzenich and Wagner 2004; Jungbluth 2005; Kannan et al. 2006; Koroneos et al. 2006a, b; Alsema and De WildScholten 2007). A wider variety of types of PV devices is available (Jäger-Waldau 2007), which may vary in their environmental benefit (Alsema 2000; Kato et al. 2001; Meijer et al. 2003; Fthenakis and Alsema 2006; Fthenakis and Kim 2007; Mohr et al. 2007; Raugei et al. 2007). The studies done so far have shown that the electricity consumption in the production process of a PV module determines a significant part of the environmental impacts of that production process because of the extensive use of fossil fuels in the energy production and the associated emissions. Based on ongoing technical developments and a growing share of renewable resources in energy supply (OECD 2008; Bakkes and Bosch 2008; IEA 2008), lower environmental impacts per unit of generated electricity are expected for the future (Frischknecht and Krewitt 2007).

A shift from fossil fuels to renewable energy sources most likely reduces the environmental impact of $\mathrm{PV}$ modules. One option is the use of PV modules as a breeder to produce the electricity that is used in the production of the same PV modules (Slesser and Hounam 1976; Gusdorf 1992). A comparison of the environmental impacts of PV modules in case their life cycle is based on the use of PV electricity in contrast to fossil electricity can elucidate potential environmental drawbacks in an early stage of development of a solar-based economy. Recently, Pacca et al. (2007) reported $68 \%$ reduction of the $\mathrm{CO}_{2}$ emission for a multicrystalline silicon (multi-Si) module and $82 \%$ reduction of the $\mathrm{CO}_{2}$ emission for a module based on thin-film triple-junction amorphous $\mathrm{Si}$, in case that PV electricity instead of conventionally generated electricity is applied in the manufacturing of the PV modules. However, they did not report effects on toxicity impacts.

The goal of this paper is to assess the environmental performance of a thin-film GaInP/GaAs solar module and a multi-Si solar module in case their life cycle is based on the 
use of PV electricity. For each of the modules, we substituted the total amount of fossil electricity required in the life cycle of the module with electricity that is generated by the corresponding PV module. Environmental impact scores are compared with those of the same solar modules in case their life cycle is based on the use of fossil electricity. For the GaInP/GaAs module, the environmental impacts of the individual production steps are also analysed in order to identify the steps with the highest relative impacts and thus with the best possibilities for system optimisation. Finally, uncertainties due to missing information for the thin-film GaInP/GaAs module are discussed with a focus on global warming and freshwater aquatic ecotoxicity scores.

\section{Materials and methods}

\subsection{Product specification of the PV modules}

The functional unit in the present study is a PV module with 1 kilowatt peak power $\left(\mathrm{kW}_{\mathrm{p}}\right)$ at an annual irradiation of $1000 \mathrm{kWh} / \mathrm{m}^{2}$ in Western Europe. The thin-film GaInP/ GaAs module is based on a gallium-indium phosphide/ gallium arsenide $\left(\mathrm{Ga}_{x} \mathrm{In}_{1-x} \mathrm{P} / \mathrm{GaAs} ; x=0.51\right)$ tandem cell that has been developed at the Radboud University Nijmegen, The Netherlands. The manufacturing of the thin-film GaInP/GaAs module is described in detail by Mohr et al. (2007). Figure 1a shows the production scheme of a thin-film GaInP/GaAs solar cell. The cells are grown on a GaAs wafer in an Aixtron AIX 3000 metal-organic vapour phase epitaxy (MOVPE) reactor system (Aixtron 2007). Excess arsine and phosphine are neutralised in a gas scrubbing system. The electricity consumption in the cell growth process is high: In terms of primary energy demand, the electricity consumption in the cell growth process involved covers two thirds of the energy demand in the $\mathrm{GaInP} / \mathrm{GaAs}$ module production (Mohr et al. 2007). Fulltime operation of the reactor system corresponds to an annual production capacity of approximately $0.1 \mathrm{MW}_{\mathrm{p}}$. By means of an advanced epitaxial lift-off (ELO) technique, the solar cell is separated from the GaAs wafer (Schermer et al. 2005); the technique is assumed to allow for $95 \%$ reuse of this wafer. A solar energy conversion efficiency of the thin-film GaInP/GaAs cell of $28.5 \%$ is considered (Mohr et al. 2007). One kilowatt peak power corresponds to a GaInP/GaAs solar cell surface of $3.51 \mathrm{~m}^{2}$.

The multi-Si module is based on a multi-Si cell with $14.4 \%$ solar energy conversion efficiency. One kilowatt peak power corresponds to a multi-Si cell surface of $6.94 \mathrm{~m}^{2}$. The production is described in detail by Jungbluth and Tuchschmid (2007). Figure 1b shows the production scheme of a multi-Si cell. The production scale considered

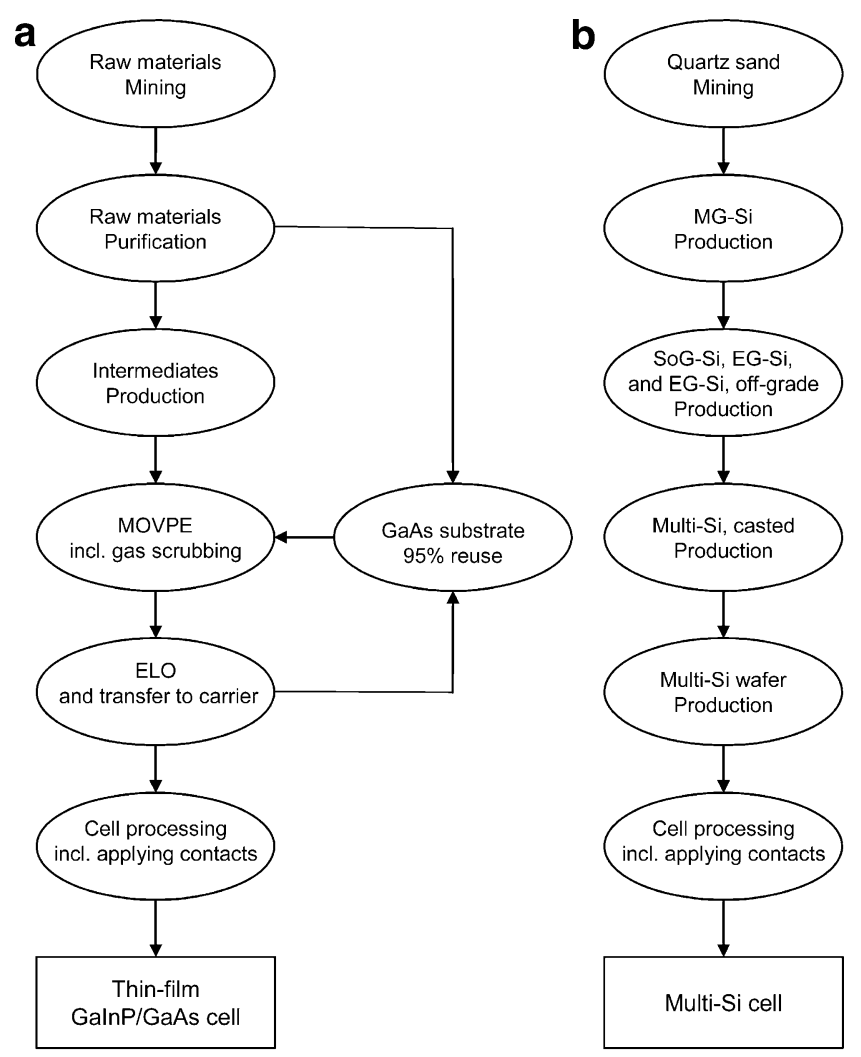

Fig. 1 Production scheme of the thin-film GaInP/GaAs solar cell (a) and the multi-Si solar cell (b)

here is larger than $1 \mathrm{MW}_{\mathrm{p}}$ per year. Silver-based contacts are applied for the GaInP/GaAs cells as well as for the multi-Si cells.

For both module types, the specification of the frame, which represents the PV module without solar cells, was derived from the $\mathrm{Si}$ solar modules as described by Jungbluth and Tuchschmid (2007). The PV modules are considered to have an expected lifetime of 30 years (Jungbluth 2005; Ecoinvent Centre 2007; United Nations Environmental Program 2008).

The Ecoinvent database, version 2.01 (Ecoinvent Centre 2007), was used as a starting point in the inventory analysis. For the production steps of the $\mathrm{GaInP} / \mathrm{GaAs}$ module which are not included within this database, the average European medium voltage mix (Ecoinvent Centre 2007) was chosen as default for electricity supply. Capital goods were included, but the clean room for the GaInP/ GaAs cells was excluded due to lack of data. Both PV systems that generate the PV electricity in the solar scenario were based on the $3 \mathrm{~kW}_{\mathrm{p}}$ slanted roof installations which are described by Jungbluth and Tuchschmid (2007). Both PV systems include a mounting system. For the GaInP/ GaAs cells, the disposal phase was excluded because there is no certainty about the actual post-consumption phase when 30 years from now the modules are disposed. 


\subsection{Electricity supply scenarios}

For the environmental evaluation of the solar modules, two scenarios were considered regarding the energy sources of the electricity used: the basic scenario (scenario 0 ) and the scenario based on solar electricity supply (scenario S). Scenario 0 calculates the environmental impacts of each solar module by use of conventional electricity, which is associated with fossil fuels demand. In the solar scenario S, for each module type, the total amount of fossil electricity in the electricity mixes that are required in the life cycle of each module, and in the associated background processes, is substituted with PV electricity. The PV electricity is generated by the same PV modules. In scenario $\mathrm{S}$, in terms of fossil Cumulative Energy Demand (CED), net 14 GJ/ $\mathrm{kW}_{\mathrm{p}}(46 \%$ of the total CED) is substituted in case of the $\mathrm{GaInP} / \mathrm{GaAs}$ module and $10 \mathrm{GJ} / \mathrm{kW}_{\mathrm{p}}(42 \%$ of the total CED) in case of the multi-Si module. Fossil electricity is defined as electricity generated from hard coal, brown coal, industrial gas, natural gas, mine gas, oil, and peat. Electricity that is generated with nuclear energy, hydropower, wind energy or solar energy is not substituted. The PV electricity that is used in the life cycle of the PV modules is generated by PV systems that include the balance-of-system components, such as the inverter and the cables. Maintenance of the PV systems and their disposal phase were also included. As the grid in most Western European countries currently allows for substantial additional input of solar power without adaptation (including the addition of storage facilities), the grid is used as a backup system for temporary surplus of the generated PV electricity.

\subsection{Environmental impact assessment methodology}

The life cycle impacts of both modules are assessed with the CML 2001 midpoint life cycle impact assessment method (Guinée 2002). Because toxicity impacts in particular may depend on the time horizon which is taken into account, the toxicity impacts are assessed for two time horizons (a time horizon of 100 years, and an infinite time horizon). Calculations were performed with SimaPro 7.1.8 (PRé Consultants 2008). To ease mutual comparison of the indicated impact scores, all impact scores are normalised for the situation in the world in 1995.

For the quantification of the environmental impacts of the individual production steps and for the sensitivity analysis, global warming and freshwater aquatic ecotoxicity were considered. Global warming scores reflect mainly the $\mathrm{CO}_{2}$ emissions associated with fossil-fuel combustion. Toxicity scores are related to both fossil-fuel combustion and processes not associated with energy production or consumption.

\section{Results and interpretation}

\subsection{Environmental impact scores}

We calculated the normalised environmental impact scores of both PV modules, for scenario 0 as well as for scenario S. The results are shown in Fig. 2. For each of both scenarios, it is found that the environmental scores of the GaInP/GaAs module have the same order of magnitude as the corresponding scores of the multi-Si module.

Because relative differences are most important for life cycle comparison, the ratios between single scores of the modules are calculated. Figure 3 shows for each PV module the ratios between the normalised environmental impact scores for scenario 0 and the corresponding scores for scenario $\mathrm{S}$. A ratio larger than 1 indicates that the impact score in scenario $\mathrm{S}$ is reduced in comparison with the corresponding score in scenario 0 . For both modules, it is found that the impact scores which are mainly related to fossil-fuel combustion, i.e. abiotic depletion, acidification, global warming, marine aquatic ecotoxicity, and photochemical oxidation, have the highest decrease in impact scores when fossil electricity is replaced by $\mathrm{PV}$ electricity. For the GaInP/GaAs module, it is found that the impact scores decrease up to a factor of 4.9 (global warming) when fossil electricity is replaced by PV electricity. For the multi-Si module, the impact scores decrease up to a factor of 2.5 (abiotic depletion and global warming) when fossil electricity is replaced by PV electricity. Furthermore, for both $\mathrm{PV}$ modules, it is found that the reductions of the impact scores for toxicity are smaller or negligible. This is caused by the decrease in use of fossil fuels, on the one hand, and an increased consumption of materials for the production of the additional solar modules used for generating the required PV electricity on the other. An analysis in more detail of the processes which dominantly contribute to the toxicity categories indicates for the $\mathrm{GaInP} / \mathrm{GaAs}$ module, that the production of chromium steel which is applied in the cell growth reactor system is most important. For the multi-Si module, the production of aluminium that is applied in the module frame dominantly contributes. Figure 3 shows that the decrease in environmental impact of the $\mathrm{GaInP} / \mathrm{GaAs}$ module is larger than the decrease in environmental impact of the multi-Si module when PV electricity is used instead of fossil electricity. This leads to a shift in ranking of several environmental impacts, such as global warming and acidification (see Fig. 2). The results of a comparative life cycle assessment (LCA) can thus be dependent of the electricity mix used in the life cycles of the assessed products.

It is found that the global warming score reduction of the multi-Si module ensued from our study (a factor of $2.5=$ $60 \%$ ) is close to the $\mathrm{CO}_{2}$ emission reduction of the multi-Si module reported by Pacca et al. (2007; 68\%). Differences between the two estimates can be explained by assumptions 


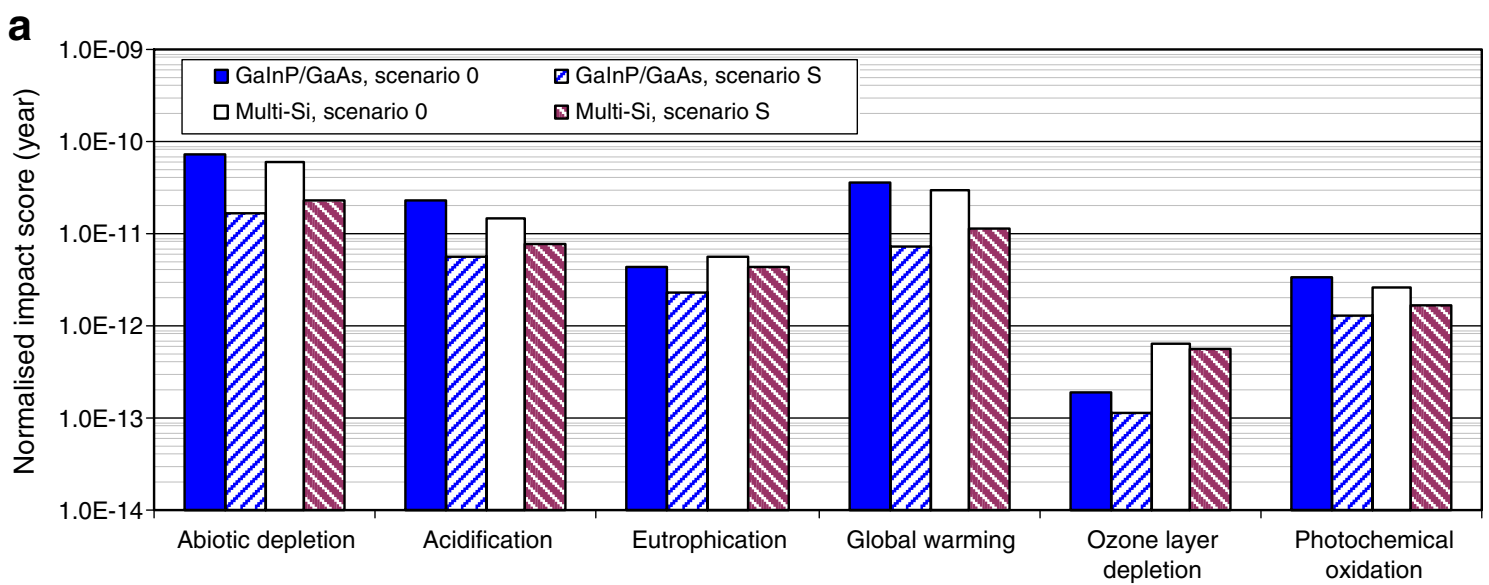

Environmental impact category

b

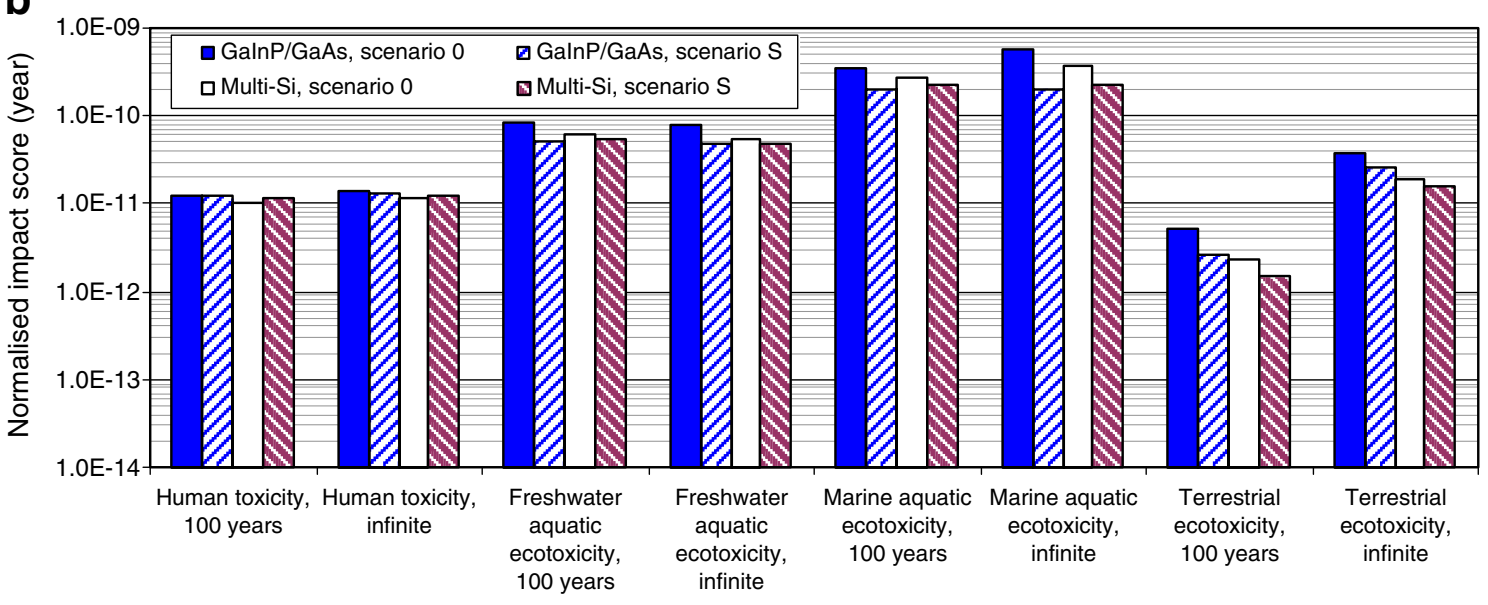

Environmental impact category

Fig. 2 Normalised impact scores, in years, of the thin-film GaInP/ GaAs module and the multi-Si module, per $1 \mathrm{~kW}_{\mathrm{p}}$. The life cycle scores are calculated with the CML 2001 method. For six impact categories, one time horizon is taken in account (a), and for the four toxicity categories, two time horizons are considered (b). All scores are normalised to the situation in the world in 1995. Scenario 0 represents the use of fossil electricity, while scenario $\mathrm{S}$ represents the

in the study performed by Pacca et al. (2007) that are different from the present study, such as a solar conversion efficiency of the multi-Si module of $12.9 \%$ instead of $13.2 \%$ in our study, and different amounts and types of electricity which are replaced by PV electricity.

\subsection{Environmental impacts of the production steps of the GaInP/GaAs module}

By means of a contribution analysis of the GaInP/GaAs module production steps, normalised scores are calculated for global warming and for freshwater aquatic ecotoxicity for both scenario 0 and scenario $\mathrm{S}$. The results are given in Fig. 4. Each individual production step includes, unless otherwise mentioned, its background processes. Regarding use of electricity generated by a corresponding module (see scenario descriptions 0 and $\mathrm{S}$ ). The average annual solar irradiation is $1000 \mathrm{kWh} / \mathrm{m}^{2}$. The production is considered for average European circumstances on a production scale of $0.1 \mathrm{MW}_{\mathrm{p}}$ per year for the $\mathrm{GaInP} / \mathrm{GaAs}$ system and a production scale of at least $1 \mathrm{MW}_{\mathrm{p}}$ per year for the multi-Si system. A high impact score means a high negative effect on the environment

the global warming scores, the energy consumption in the cell growth process is dominant in scenario 0 . In scenario $\mathrm{S}$, the impact of the cell growth process on global warming is reduced with a factor of about 25 . The global warming scores in scenario $\mathrm{S}$ are dominated by the frame and the final cell processing. Regarding the freshwater aquatic ecotoxicity scores, it is found that the energy consumption in the cell growth process is dominant in scenario 0 . In scenario $\mathrm{S}$, the following production steps have the highest contributions: the MOVPE reactor system with the gas scrubbing system (which are composed of stainless steel), the frame (which for a large part is based on aluminium and glass) and the cell growth process (caused by the electricity consumption). Contribution analysis results for the other impact categories can be found in the Electronic supplementary material. 


\section{a}

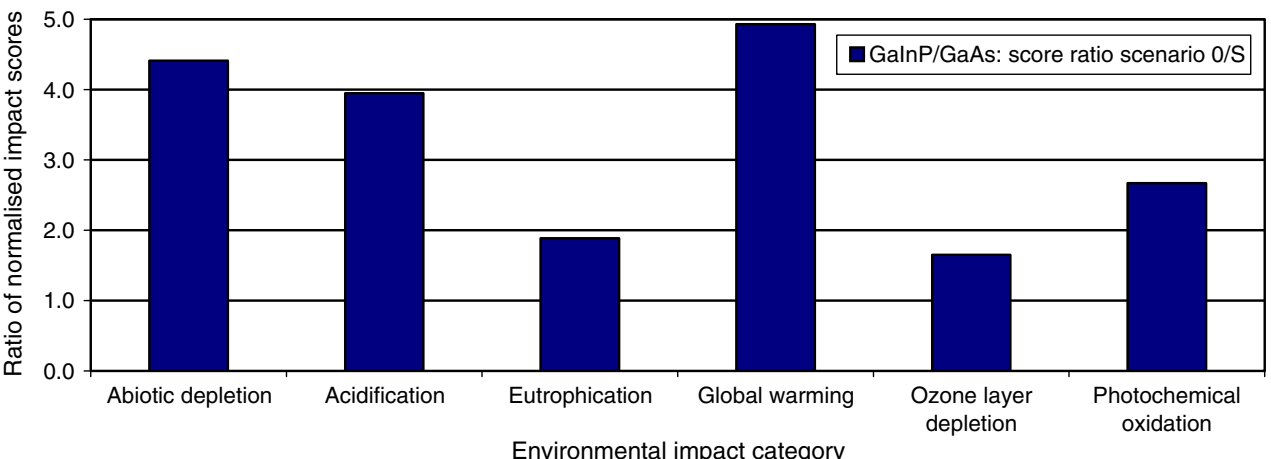

\section{b}

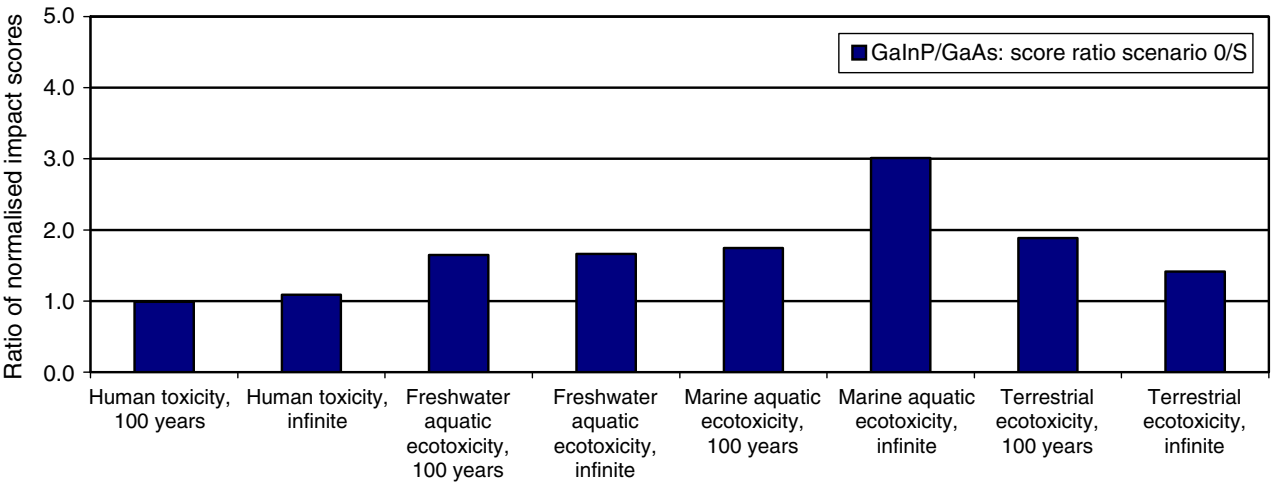

Environmental impact category

\section{C}

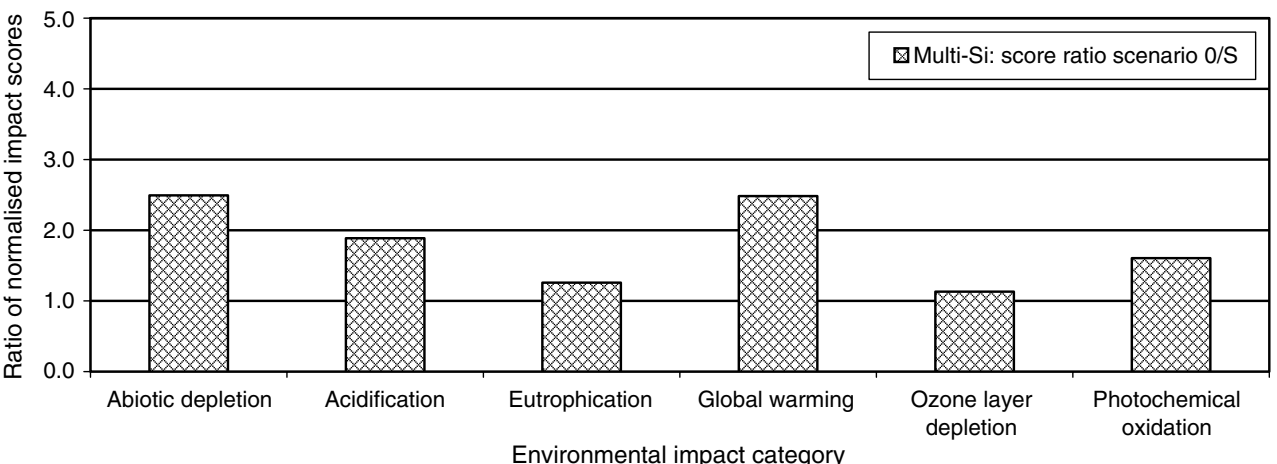

d

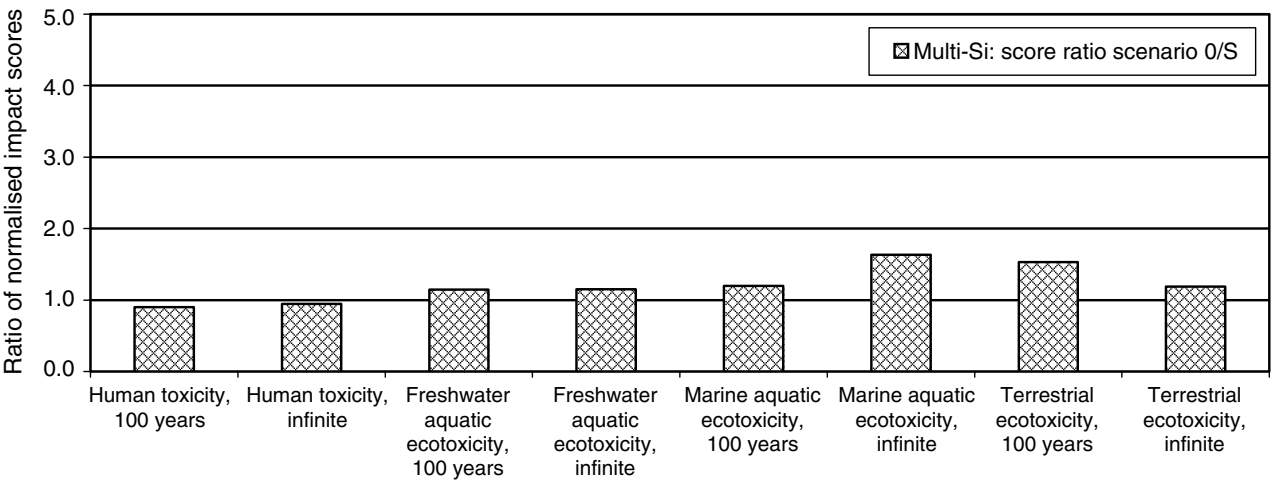

Environmental impact category 
Fig. 3 Ratios of normalised environmental impact scores between two electricity supply scenarios for the thin-film $\mathrm{GaInP} / \mathrm{GaAs}$ module $(\mathbf{a}, \mathbf{b})$ and for the multi-Si module (c, d). Scenario 0 represents the supply with conventional electricity, and scenario $\mathrm{S}$ represents supply on the basis of PV electricity. Scenario S reflects the net substitution of an amount of fossil electricity with a CED of $14 \mathrm{GJ} / \mathrm{kW}_{\mathrm{p}}$ for the GaInP/ GaAs module and $10 \mathrm{GJ} / \mathrm{kW}_{\mathrm{p}}$ for the multi-Si module. A ratio $>1.0$ means that there is an environmental advantage for the solar powered production

The contribution analysis for global warming and for freshwater aquatic ecotoxicity shows that the impact scores of the cell growth process are strongly decreased when PV electricity instead of fossil electricity is used in this process. A further decrease can be achieved by improvement of the efficiency of the cell growth process and by reducing the electricity consumption in this process (Mohr et al. 2007).
The contribution analysis for freshwater aquatic ecotoxicity shows further for both scenarios that a reduction of the amount of stainless steel in the MOVPE reactor and the gas scrubbing systems, and a longer lifetime of these systems will be the most effective to obtain a reduction of these toxicity scores of the $\mathrm{GaInP} / \mathrm{GaAs}$ cells.

\section{Discussion}

In this section, the uncertainties in the analysis will be discussed, with a specific focus on the influence of uncertainty in the inventory analysis of the $\mathrm{GaInP} / \mathrm{GaAs}$ module on the environmental performance for global warming and freshwater aquatic ecotoxicity.

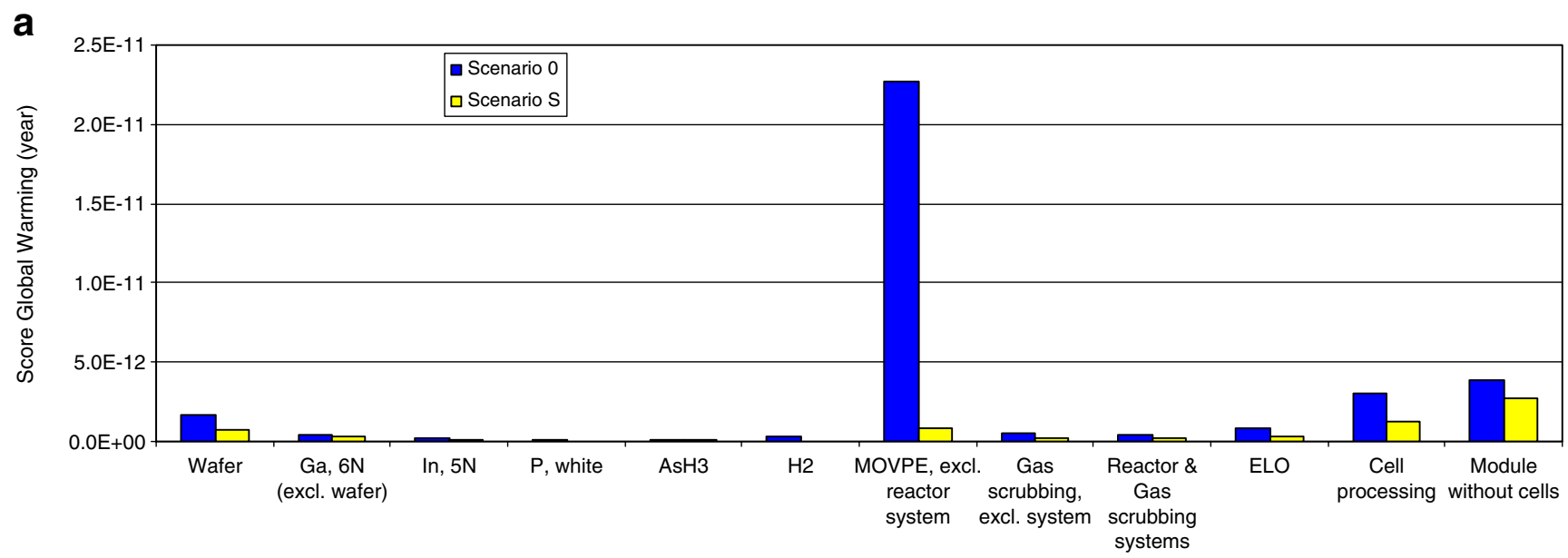

b

Part of the production of $1 \mathrm{kWp}$ thin-film GalnP/GaAs module

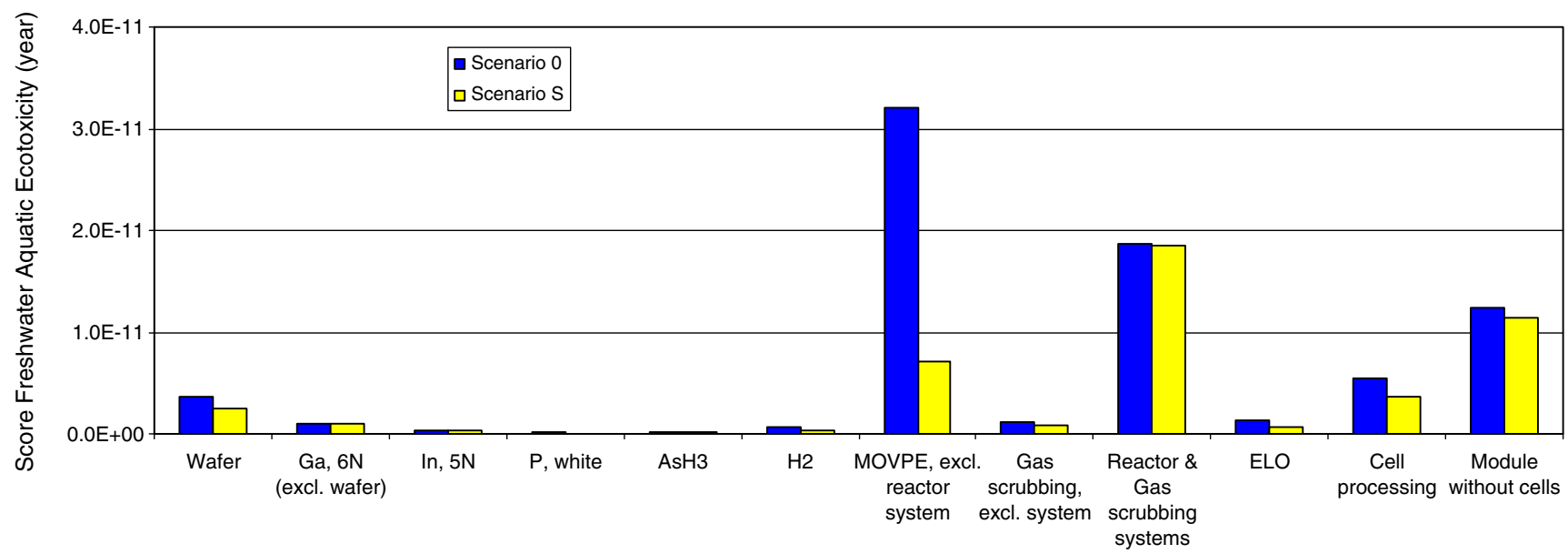

Part of the production of $1 \mathrm{kWp}$ thin-film GalnP/GaAs module

Fig. 4 Environmental impact scores, in years, of the production steps of the thin-film GaInP/GaAs module, per $1 \mathrm{~kW}_{\mathrm{p}}$, calculated with the CML 2001 method for global warming (a) and freshwater aquatic ecotoxicity (b; infinite time horizon), with normalisation to the situation in the world in 1995 . Scenario 0 represents supply with conventional electricity, and scenario $\mathrm{S}$ represents supply on the basis of PV electricity. Each individual production step includes, unless otherwise mentioned, its background processes. The impact scores associated with the production of nitrogen are not included in the figure due to their relatively small magnitudes 
Table 1 The influence of uncertainties on the global warming score and the freshwater aquatic ecotoxicity score (for an infinite time horizon) of the thin-film GaInP/GaAs module in scenario 0 and scenario $\mathrm{S}$, respectively

\begin{tabular}{|c|c|c|c|c|c|c|c|}
\hline \multirow[t]{3}{*}{ Case } & \multirow[t]{3}{*}{ Parameter } & \multirow{3}{*}{$\begin{array}{l}\text { Approximation applied } \\
\text { in the present LCA }\end{array}$} & \multirow{3}{*}{$\begin{array}{l}\text { Substitute in alternate } \\
\text { situation }\end{array}$} & \multicolumn{4}{|c|}{ Change $^{\mathrm{a}}$ in score $(\%)$} \\
\hline & & & & \multicolumn{2}{|c|}{ Global warming } & \multicolumn{2}{|c|}{$\begin{array}{l}\text { Freshwater aquatic } \\
\text { ecotoxicity }\end{array}$} \\
\hline & & & & Scenario 0 & Scenario $\mathrm{S}$ & Scenario 0 & Scenario $\mathrm{S}$ \\
\hline 1 & Allocation of gallium & $\begin{array}{c}0 \% \text { for gallium in Bayer } \\
\text { liquor } / 100 \% \text { for } \mathrm{Al}_{2} \mathrm{O}_{3}\end{array}$ & $\begin{array}{c}6 \% \text { for gallium in Bayer } \\
\text { liquor } / 94 \% \text { for } \mathrm{Al}_{2} \mathrm{O}_{3}\end{array}$ & +5.1 & +21 & +120 & +200 \\
\hline 2 & Allocation of $\mathrm{As}_{2} \mathrm{O}_{3}$ & $\begin{array}{l}0 \% \text { for } \mathrm{As}_{2} \mathrm{O}_{3} / 100 \% \\
\text { for } \mathrm{Cu}\end{array}$ & $\begin{array}{l}0.47 \% \text { for } \mathrm{As}_{2} \mathrm{O}_{3} / 99.53 \% \\
\text { for } \mathrm{Cu}\end{array}$ & +0.0 & +0.1 & +0.3 & +0.4 \\
\hline 3 & $\begin{array}{l}\text { Lifetime of the reactor } \\
\text { and gas scrubbing systems } \\
\text { for the GaInP/GaAs cell } \\
\text { production }\end{array}$ & 20 years & 10 years & +1.1 & +3.8 & +24 & +42 \\
\hline 4 & $\begin{array}{l}\text { Conversion efficiency } \\
\text { of the commercially } \\
\text { produced GaInP/GaAs } \\
\text { cells }\end{array}$ & $28.5 \%$ & $27.0 \%$ & +5.6 & +6.0 & +5.6 & +6.3 \\
\hline 5 & $\begin{array}{l}\text { Trimethyl compounds: } \\
\text { energy in production } \\
\text { process }\end{array}$ & Zero & $\begin{array}{l}50 \% \text { of primary energy } \\
\text { demand in production } \\
\text { of } \mathrm{Ga} 6 \mathrm{~N} \text {, resp. In } 5 \mathrm{~N}\end{array}$ & +2.3 & +0.4 & +1.4 & +0.5 \\
\hline 6 & $\begin{array}{l}\text { GaAs wafer: energy input } \\
\mathrm{CZ} \text { production process }\end{array}$ & $\begin{array}{l}\text { Derivation on the basis } \\
\text { of energy input } \mathrm{CZ} \mathrm{Si} \\
\text { wafer production }\end{array}$ & $\begin{array}{l}2 \text { times the energy input } \\
\text { that is derived on the basis } \\
\text { of energy input } \mathrm{CZ} \mathrm{Si} \\
\text { wafer production }\end{array}$ & +0.8 & +0.1 & +0.5 & +0.2 \\
\hline 7 & $\begin{array}{l}\text { Yield GaInP/GaAs cell } \\
\text { growth process }\end{array}$ & Process data & $\begin{array}{l}10 \% \text { less yield of aimed } \\
\text { cell materials and } 10 \% \\
\text { less deposition of non- } \\
\text { controlled materials than } \\
\text { in process data }\end{array}$ & +8.5 & +3.9 & +5.7 & +3.1 \\
\hline 8 & $\begin{array}{l}\text { Electricity mix consumed } \\
\text { in the reactor and gas } \\
\text { scrubbing systems } \\
\text { for the GaInP/GaAs } \\
\text { cell production }\end{array}$ & $\begin{array}{l}\text { Average European } \\
\text { medium voltage electricity } \\
\text { mix }(0.52 \mathrm{kWh} \text { fossil } \\
\text { electricity per } \mathrm{kWh} ; \\
57 \% \text { of its CED) }\end{array}$ & $\begin{array}{l}\text { Average Norwegian } \\
\text { medium voltage electricity } \\
\text { mix }(0.0041 \mathrm{kWh} \text { fossil } \\
\text { electricity per } \mathrm{kWh} ; \\
2.3 \% \text { of its CED) }\end{array}$ & -66 & -6.4 & -40 & -12 \\
\hline 9 & $\begin{array}{l}\text { 'Worst-case' combination } \\
\text { of numbers } 1,2,3 \text {, } \\
4,5,6 \text {, and } 7\end{array}$ & $\begin{array}{l}\text { See case numbers } 1,2,3 \text {, } \\
4,5,6 \text {, and } 7\end{array}$ & $\begin{array}{l}\text { See case numbers } 1,2,3 \text {, } \\
\quad 4,5,6 \text {, and } 7\end{array}$ & +28 & +41 & +180 & +300 \\
\hline
\end{tabular}

a + means higher impact score

In line with the Ecoinvent database v2.01 (Ecoinvent Centre 2007), our calculations are based on economic allocation rules (Guinée et al. 2004). Each economic allocation depends, however, on circumstances such as place, time and the production process involved. Therefore, economic allocations can be associated with uncertainty. In particular, for substances which are produced in several ways, with (partly) confidential production data, in estimated amounts, and with a strongly varying supply and demand on the global market, calculated environmental impacts can be affected by economic allocation values. For both gallium $(\mathrm{Ga})$ and arsenic trioxide $\left(\mathrm{As}_{2} \mathrm{O}_{3}\right)$, the influence of different allocation values is considered more in detail here. Gallium is mainly formed as a by-product of aluminium, e.g. in the so-called Bayer liquor besides aluminium trioxide $\left(\mathrm{Al}_{2} \mathrm{O}_{3}\right)$. In line with Ecoinvent data- base v2.01, an economic value of zero for gallium is considered as default. As an alternative, gallium is allocated on the basis of average prices of gallium and aluminium trioxide in the period 2004-2006 (U.S. Geological Survey 2006-2007). $\mathrm{As}_{2} \mathrm{O}_{3}$ is formed as a by-product of copper $(\mathrm{Cu})$, whereby an economic value of zero is considered as default for $\mathrm{As}_{2} \mathrm{O}_{3}$. As an alternative, $\mathrm{As}_{2} \mathrm{O}_{3}$ is allocated on the basis of average prices of $\mathrm{As}_{2} \mathrm{O}_{3}$ and copper in the period 2004-2006 (U.S. Geological Survey 2006-2007).

Moreover, uncertainties in the following life cycle parameters are considered, which were also included in our previous study about the production process of the GaInP/GaAs module (Mohr et al. 2007):

- the efficiency of commercially produced $\mathrm{GaInP} / \mathrm{GaAs}$ cells; 
- the energy consumed in the production of the trimethyl compounds and the GaAs wafer; and

- the yield of the $\mathrm{GaInP} / \mathrm{GaAs}$ cell growth process.

Furthermore, uncertainty about the lifetime of the reactor and the gas scrubbing systems is taken into account. For the existing systems, an average lifetime of 20 years is expected, but a lifetime of 10 years is considered as an alternative. Finally, uncertainty associated with the applied electricity mix is taken into account. The average European medium voltage electricity mix (Ecoinvent Centre 2007) is applied as default, while the average Norwegian medium voltage electricity mix, which is mainly based on hydropower, is considered as an alternative. For this, the electricity demand in the cell growth process is considered because this process has the largest share in the electricity demand of the $\mathrm{GaInP} / \mathrm{GaAs}$ module.

Table 1 shows that global warming scores vary between $-66 \%$ and $+28 \%$ for scenario 0 , and between $-6.4 \%$ and $+41 \%$ for scenario $\mathrm{S}$. Freshwater aquatic ecotoxicity scores vary between $-40 \%$ and $+180 \%$ for scenario 0 , and between $-12 \%$ and $+300 \%$ for scenario S. For both impact categories, the uncertainties associated with the allocation of gallium, with the composition of the electricity mix used in the reactor system for the cell growth process and the gas scrubbing system, with the conversion efficiency of the commercially produced $\mathrm{GaInP} / \mathrm{GaAs}$ cells, and with the yield of the cell growth process are relatively high in both scenarios. For freshwater aquatic ecotoxicity, the uncertainty caused by the lifetime of the reactor system for the cell growth process and the gas scrubbing system is relatively high in both scenarios. The uncertainty of the worst-case is not equal to the sum of the uncertainties found for the individual parameters involved because the uncertainties of these parameters are not independent. Furthermore, when comparing per impact category the best- and the worst-case uncertainties in scenario 0 with those in scenario $\mathrm{S}$, it appears that they vary more than one order of magnitude. This means that the substitution of fossil electricity by PV electricity affects the sensitivity analysis results.

Additional uncertainties are caused by missing data about the energy consumption of the clean room, and by missing data about the arsine emissions during the ELO process. For the multi-Si module, there are also uncertainties regarding a number of inventory data (Jungbluth and Tuchschmid 2007). These uncertainties are mainly associated with the production techniques considered, e.g. the energy demand in the solar grade silicon (SoG-Si) production process and the emissions occurring in the production process. Uncertainties about light absorption by glass applied in the module, and uncertainties about the solar cell surface needed to reflect $1 \mathrm{~kW}_{\mathrm{p}}$ are similar for both modules.
Because actually received solar irradiation varies, among other things, with the time of the day (during night-time in Western Europe, the irradiation even becomes zero), it will not be possible to produce PV modules in a full-time production process only by PV electricity without an appropriate back-up system for PV electricity. In studying the effect of replacement of fossil electricity by PV electricity on the environmental burdens, we have assumed that back-up of the PV electricity occurs through the grid. Application of PV electricity on an extended scale, however, will additionally require storage-type back-up systems (Denholm and Margolis 2007). Using these back-up systems will lead to an increase of the calculated environmental impacts of both the GaInP/GaAs module and the multi-Si module, but the quantitative impact thereof could not be estimated. Furthermore, for the solar scenario, we have assumed the cell and module production techniques and the techniques for the underlying and other associated processes, such as recycling, to be the same as current techniques. In the future, however, improved silicon, crystal, wafer, cell and module production techniques and other technical developments, which will improve the environmental performance of the devices, are expected.

The highest normalised impact scores are found for marine freshwater aquatic toxicity. Marine aquatic ecotoxicity scores are largely related with emissions of metals. Although those emissions are rather uncertain as yet, the marine aquatic ecotoxicity scores have been indicated because it is felt that there may well be significant effects of changes in metal concentrations on marine aquatic ecosystems. It can be noted that there is much uncertainty concerning these effects, and to the representation thereof in current LCA methodology.

\section{Conclusions}

The environmental burdens of a thin-film GaInP/GaAs solar module and a multicrystalline silicon module have been assessed in case their life cycle is based on the use of electricity that is generated by the corresponding PV modules. Comparison with the environmental burdens of the solar modules in case their life cycle is based on the use of conventionally generated electricity indicates a reduction, particularly of the impacts on global warming, abiotic depletion, acidification, and photochemical oxidation. The reductions of the toxicity scores, however, are smaller or negligible. This is caused by a decreased use of fossil fuels, on the one hand, and an increased consumption of materials for the production of the additional solar modules used for generating the required PV electricity on the other. 
For both PV modules, it is shown that full replacement of fossil electricity by PV electricity reduces the environmental burdens, particularly the fossil-fuel-related impacts such as impacts on global warming (see Fig. 3). Because the greenhouse gas emissions associated with the production of fossil-fuel-based electricity have a substantial share in global warming on a world-wide scale, switching to a more extensive use of solar power is helpful to comply with the present international legislation on the area of global warming reduction. As reductions in toxicity impact scores are smaller or negligible when fossil electricity is replaced by PV electricity, it is desirable to give specific attention to the processes which dominantly contribute to these impact categories. For the GaInP/GaAs module, it mainly concerns the production of chromium steel that is applied in the cell growth reactor system, and for the multi-Si module, it mainly concerns the production of aluminium that is applied in the module frame.

In this study, a shift in ranking of several environmental impacts of the modules has been found when PV electricity is used instead of fossil electricity. The results of a comparative LCA can thus be dependent of the electricity mix used in the life cycles of the assessed products.

Acknowledgements The authors thank the reviewers of the paper for their useful comments.

Open Access This article is distributed under the terms of the Creative Commons Attribution Noncommercial License which permits any noncommercial use, distribution, and reproduction in any medium, provided the original author(s) and source are credited.

\section{References}

Aixtron (2007) AIX 3000. Aixtron, Aachen, Germany. http://www. aixtron.com and personal communication, July/October 2007

Alsema EA (2000) Energy pay-back time and $\mathrm{CO}_{2}$ emissions of PV systems. Progr Photovolt Res Appl 8:17-25

Alsema EA, De Wild-Scholten MJ (2007) Reduction of the environmental impacts in crystalline silicon module manufacturing. 22nd European Photovoltaic Solar Energy Conference, 3-7 September 2007, Milan, Italy, 2BP.1.4

Bakkes JA, Bosch PR (eds) (2008) Background report to the OECD Environmental Outlook to 2030. MNP/OECD, MNP Report 500113001/2008. Netherlands Environmental Assessment Agency, Bilthoven, The Netherlands

Denholm P, Margolis RM (2007) Evaluating the limits of solar photovoltaics (PV) in traditional electric power systems. Energ Policy 35:2852-2861

Dones R, Heck T, Hirschberg S (2004) Greenhouse gas emissions from energy systems: Comparison and overview. In: Cleveland C (ed) Encyclopedia of Energy. Academic Press/Elsevier, San Diego, USA. Vol. 3, pp 77-95

Ecoinvent Centre (2007) Ecoinvent Data v2.01. Swiss Centre for Life Cycle Inventories, Dübendorf, Switzerland. http://www. ecoinvent.ch (Viewed on 14 July 2008)

European Commission (1995-1998) Externalities of Fuel Cycles 'ExternE' Project. Report series. European Commission, Directorate-General
XII, Science, Research and Development JOULE, Brussels, Belgium. http://www.externe.info (Viewed on 24 January 2007)

Frischknecht R, Krewitt W (2007) NEEDS: Effective assessment of long-term sustainable energy policies in Europe by integrating LCA, external costs and energy planning models. In: Proceedings 14th SETAC Europe Case Studies Symposium: LCA of Energy - Energy in LCA, 3-4 December 2007, Göteborg, Sweden

Fthenakis VM, Alsema EA (2006) Photovoltaics energy payback times, greenhouse gas emissions and external costs: 2004-early 2005 status. Progr Photovolt Res Appl 14:275-280

Fthenakis VM, Kim HC (2007) Greenhouse-gas emissions from solar electric- and nuclear power: A life-cycle study. Energ Policy $35: 2549-2557$

Guinée JB (ed) (2002) Handbook on life cycle assessment. Kluwer, Dordrecht, The Netherlands

Guinée JB, Heijungs R, Huppes G (2004) Economic allocation: Examples and derived decision tree. Int J Life Cycle Assess 9(1):23-33

Gürzenich D, Wagner H-J (2004) Cumulative energy demand and cumulative emissions of photovoltaics production in Europe. Energy 29(12-15):2297-2303

Gürzenich D, Mathur J, Bansal NK, Wagner H-J (1999) Cumulative energy demand for selected renewable energy technologies. Int J Life Cycle Assess 4(3):143-149

Gusdorf J (1992) Energy paybacks and renewable breeders. Energy 17 (12):1137-1151

IEA (2008) IEA World Energy Outlook 2008. International Energy Agency, Paris, France

IPCC (2007) Fourth Assessment Report on Climate Change 2007. Intergovernmental Panel on Climate Change, Geneva, Switzerland

Jäger-Waldau A (2007) PV Status Report 2007. Office for Official Publications of the European Communities, Luxembourg, Luxembourg

Jungbluth N (2005) Life cycle assessment of crystalline photovoltaics in the Swiss ecoinvent database. Progr Photovolt Res Appl 13:429-446

Jungbluth N, Tuchschmid M (2007) Photovoltaics. In: Dones R et al (eds) Sachbilanzen von Energiesystemen: Grundlagen für den ökologischen Vergleich von Energiesystemen und den Einbezug von Energiesystemen in Ökobilanzen für die Schweiz. Ecoinvent report No. 6-XII. Swiss Centre for Life Cycle Inventories, Dübendorf, Switzerland

Kannan R, Leong KC, Osman R, Ho HK, Tso CP (2006) Life cycle assessment study of solar PV systems: An example of a $2.7 \mathrm{~kW}_{\mathrm{p}}$ distributed solar PV system in Singapore. Sol Energy 80:555563

Kato K, Hibino T, Komoto K, Ihara S, Yamamoto S, Fujihara H (2001) A life-cycle analysis on thin-film CdS/CdTe PV modules. Solar Energ Mat Sol C 67:279-287

Keoleian GA, McD Lewis G (2003) Modeling the life cycle energy and environmental performance of amorphous silicon BIPV roofing in the US. Renew Energ 28:271-293

Koroneos C, Stylos N, Moussiopoulos N (2006a) LCA of multicrystalline silicon photovoltaic systems. Part 1: Present situation and future perspectives. Int $\mathrm{J}$ Life Cycle Assess 11 (2):129-136

Koroneos C, Stylos N, Moussiopoulos N (2006b) LCA of multicrystalline silicon photovoltaic systems. Part 2: Application on an island economy. Int J Life Cycle Assess 11(3):183-188

Meijer A, Huijbregts MAJ, Schermer JJ, Reijnders L (2003) Life-cycle assessment of photovoltaic modules: Comparison of mc-Si, InGaP and InGaP/mc-Si solar modules. Progr Photovolt Res Appl 11:275-287

Mohr NJ, Schermer JJ, Huijbregts MAJ, Meijer A, Reijnders L (2007) Life cycle assessment of thin-film GaAs and GaInP/GaAs solar modules. Progr Photovolt Res Appl 15(2):163-179

OECD (2008) OECD Environmental Outlook to 2030. Organisation for Economic Co-operation and Development, Paris, France 
Pacca S, Sivaraman D, Keoleian GA (2007) Parameters affecting the life cycle performance of PV technologies and systems. Energ Policy 35:3316-3326

PRé Consultants (2008) SimaPro 7.1.8. PRé Consultants, Amersfoort, The Netherlands. http://www.pre.nl (Viewed on 14 July 2008)

Quadrelli R, Peterson S (2007) The energy-climate challenge: Recent trends in $\mathrm{CO}_{2}$ emissions from fuel combustion. Energ Policy 35:5938-5952

Raugei M, Bargigli S, Ulgiati S (2007) Life cycle assessment and energy pay-back time of advanced photovoltaic modules: CdTe and CIS compared to poly-Si. Energy 32(8):1310-1318

Schermer JJ, Mulder P, Bauhuis GJ, Voncken MMAJ, Van Deelen J, Haverkamp E, Larsen PK (2005) Epitaxial lift-off for large area thin film III-V devices. Phys Status Solidi (a) 202(4):501-508
Slesser M, Hounam I (1976) Solar-energy breeders. Nature 262 (5566):244-245

United Nations Environmental Program (UNEP) Energy technology fact sheet photovoltaics (PV). Solar electricity. Retrieved from: http://www.uneptie.org/energy/act/re/fact_sheet/docs/pv.pdf (16 August 2008)

U.S. Geological Survey (2006-2007) U.S. Department of the Interior, Mineral Resources Program, USA. Arsenic in 2005 (xls-file). Arsenic in 2006 (xls-file). Bauxite and alumina in 2005 (xls-file). Bauxite and alumina in 2006 (xls-file). Copper in 2006 (xls-file). Gallium in 2005 (xls-file). Gallium in 2006 (xls-file). Retrieved from: http://minerals.usgs.gov/minerals/ pubs/commodity (July 2008) 